\title{
Nerve-sparing surgery in current gynecologic oncology
}

\section{Chirurgia oszczędzająca unerwienie w nowoczesnej ginekologii onkologicznej}

\author{
'Department of Oncological Surgery, Saint Raphael's Hospital, Krakow, Poland \\ 2 Department of Gynecology and Oncology, Jagiellonian University, Krakow, Poland \\ Correspondence: Paweł Gruszecki, Bochenka 12, 30-693 Kraków, Poland, e-mail: gruszecki.pawel@gmail.com \\ 'Klinika Chirurgii Onkologicznej i Chirurgii Ogólnej, Szpital św. Rafała w Krakowie, Kraków, Polska \\ ${ }^{2}$ Klinika Ginekologii i Onkologii w Krakowie, Uniwersytet Jagielloński, Kraków, Polska \\ Adres do korespondencji: Paweł Gruszecki, ul. Bochenka 12, 30-693 Kraków, e-mail: gruszecki.pawel@gmail.com
}

\begin{abstract}
Nerve-sparing surgery is currently a very important topic in gynecologic oncology. In this review, it is shown that radical hysterectomy is not the only operation where the nerve-sparing technique can be used. Most surgical procedures in modern gynecologic oncology should spare the autonomic nerve structures. The review includes recently published articles precisely describing the nerve-sparing techniques in paraaortic and pelvic lymphadenectomy, and the modern approach to radical nerve-sparing hysterectomy. It has been shown in the literature that the quality of life of patients is directly dependent on the operation technique and its extension. As mentioned above, the nerve-sparing technique needs to be used not only in surgical procedures for cervical cancer, but more extensively also for endometrial and ovarian cancers. Modern techniques demonstrate that such an operation can be suitable both for the radicality and improved quality of life. Results of such operations are comparable to the old - not nerve-sparing techniques - both in terms of progression-free survival and overall survival. Nerve-sparing surgery in gynecologic oncology is our future. Better quality of life and greater patient satisfaction should be our goals. Studies are needed for better examination and comparison of the presented systematic nerve-sparing operations of lymphadenectomy in ovarian and endometrial cancers, and also combined with nerve-sparing radical hysterectomy.
\end{abstract}

Keywords: nerve-sparing, radical hysterectomy, pelvic and paraaortic lymphadenectomy

Streszczenie Chirurgia oszczędzająca unerwienie jest aktualnie bardzo ważnym tematem w ginekologii onkologicznej. W niniejszej pracy zwrócono uwagę na fakt, że metoda oszczędzająca unerwienie nie jest zarezerwowana tylko dla radykalnej histerektomii. Większość procedur chirurgicznych stosowanych w nowoczesnej ginekologii onkologicznej powinna zachowywać unerwienie autonomiczne. W artykule omówiono ostatnio opublikowane prace precyzyjnie opisujące technikę oszczędzania unerwienia w usuwaniu węzłów biodrowych i okołoaortalnych, jak również nowoczesny sposób przeprowadzania oszczędzającej unerwienie radykalnej histerektomii. W dostępnym piśmiennictwie potwierdzono, że jakość życia pacjentki jest bezpośrednio związana z techniką operacyjną oraz rozległością zabiegu. Jak wspomniano wcześniej, technika operacyjna oszczędzająca unerwienie powinna być stosowana nie tylko w operacjach raka szyjki macicy, ale znacznie częściej - w operacjach raka endometrium oraz raka jajnika. Nowoczesne techniki pokazują, że ten rodzaj operacji zapewnia radykalność, a także pozwala pacjentowi zachować wysoką jakość życia. Rezultaty tego rodzaju zabiegów są porównywalne z technikami standardowymi bez oszczędzania unerwienia - jeżeli chodzi o okres wolny od wznowy nowotworu oraz całkowite przeżycie. Chirurgia oszczędzająca unerwienie jest przyszłością ginekologii onkologicznej. Lepsza jakość życia oraz satysfakcja pacjentek jest naszym celem. Konieczne są jednak dalsze badania kliniczne dla lepszego zbadania i porównania prezentowanych w niniejszej pracy operacji oszczędzających unerwienie w usuwaniu węzłów chłonnych w raku jajnika i raku endometrium, jak również w połączeniu z oszczędzającą unerwienie histerektomią radykalną.

Słowa kluczowe: oszczędzanie unerwienia, histerektomia radykalna, usunięcie węzłów chłonnych biodrowych i okołoaortalnych 


\section{INTRODUCTION}

I $\mathrm{n}$ the last years, a lot of studies have been focusing on nerve-sparing hysterectomies. But looking at nervesparing surgery in gynecologic oncology, radical hysterectomy is not the only operation where the nerve-sparing technique should be used. Modern gynecologic oncology is focused not only on tumor operation, but also on the aspects of the quality of life. Patients after radical surgery are often affected by problems with the bladder, bowel (rectal) or sexual functions. Consequently, current gynecologic oncology is oriented towards operative techniques which in addition to radicality spare the functions for the better life quality. As mentioned before, nerve-sparing surgery in gynecologic oncology should be implemented in almost every operation where radical hysterectomy or pelvic and paraaortic lymphadenectomy is performed. It means that not only patients with cervical cancer need to be operated on by a nerve-sparing technique, but also patients with endometrial and ovarian cancers. Nerves should be spared on each level of the nerve system where the surgeon closes up to the nerve structures. Looking from cranial to caudal in lymphadenectomy, the first to be spared are the nerves close to the aorta and vena cava, and then the focus should be moved to the nerves in the presacral region. Nerve-sparing radical hysterectomy is then the lowest level of the operation where the nerve-sparing technique should be implemented.

In this review, the authors focused on the studies spanning the last two years in which the nerve system and radical operative techniques were examined. Two recent papers by Muallem address the nerve-sparing operations in gynecologic oncology ${ }^{(1,2)}$. New studies, which have been published recently, show that gynecologic oncology and operative techniques are still in development. There is a lot to learn and to understand, in order to make the life of the patients better.

\section{HISTORY OF RADICAL SURGERY IN GYNECOLOGY}

At the beginning, a short summary of the history of operative treatment in gynecologic oncology seems in order. The first descriptions of gynecologic surgery can be found in the book by Thorwald entitled Die Frauenärzte. In the $19^{\text {th }}$ century, the first operation of an ovarian tumor was performed. The surgeon had to be very fast and precise for a successful effect, and most of the tumors treated were benign.

The German surgeon Wilhelm Alexander Freund undertook the first ever abdominal extirpation of a cancerous uterus on January 30, 1878. In 1898, Ernst Wertheim, a Viennese physician, developed the technique of radical total hysterectomy with the removal of the pelvic lymph nodes and the parametrium. In 1905, he reported the outcomes of his first group of 270 patients. The operative mortality rate was $18 \%$, and the major morbidity rate was $31 \%{ }^{(3)}$. In 1912, Wertheim reported on his first 500 operations, and

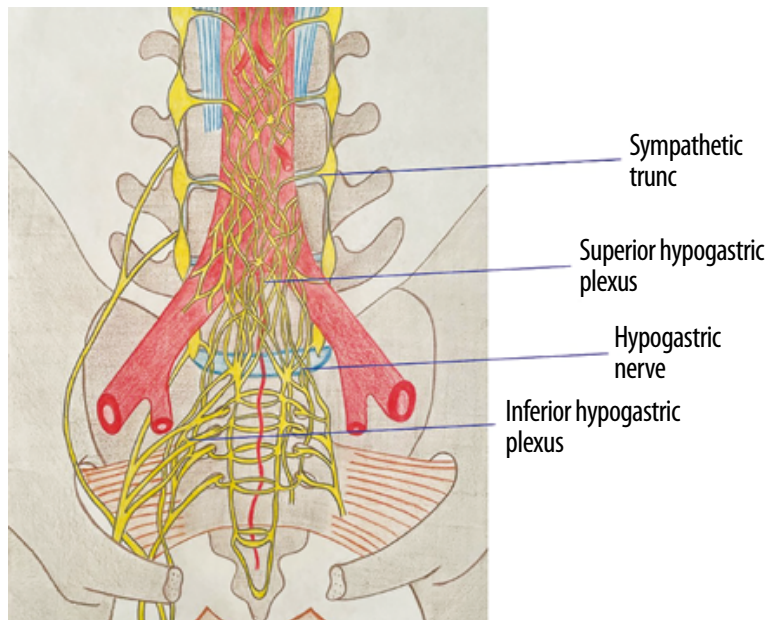

Fig. 1. Anatomy of nerve structures

In 1919, Latzko and Schiffmann described the anatomy and technique of the radical operation of cervical cancer ${ }^{(4)}$. They advocated that the uterus needed to be removed along with the supporting structures including the cardinal ligament, uterosacral ligament, and vesicouterine ligament.

In Japan, the radical procedure was performed by Okabayashi roughly at the same time, in $1921^{(5)}$. A characteristic feature of the Okabayashi surgical formula was that the anterior and posterior layers of the vesicouterine ligaments were dissected, allowing extensive resection of the parametrial and paravaginal tissues. This part of the procedure was the most significant change compared to Latzko's technique. Okabayashi was also the first surgeon to attempt isolation of the nerve structures in the posterior part of the uterus supporting structures - the Okabayashi space is described in the next part of this paper.

In 1944, Meigs repopularized the surgical approach by developing a modified Wertheim operation involving the removal of all pelvic nodes. This method of the radical operation in cervical cancer became a standard until $1990^{(6)}$. Such operation techniques, however, were commonly complicated by bladder paralysis and deficiency in sexual function, and also defecation problems.

In 1990, Yabuki presented the first radical operation with sparing of the bladder nerves ${ }^{(7)}$. In his opinion, the most important aspect in terms of preserving bladder function was to spare the inferior hypogastric plexus, which consists of nerve bundles from the hypogastric nerve and pelvic splanchnic nerves. The dissection of the vesicouterine ligament creates the Yabuki fourth space and allows to spare the bladder nerves ${ }^{(8)}$.

In the late 1990s, Höckel et al. presented his new operative technique within embryologic compartments, preserving the neural function ${ }^{(9)}$. In fact, the technique was a modification of the Wertheim procedure. The TMMR method removes the uterus with its supporting structures and, if it is possible, spares the nerves. Höckel divided the supporting structures of the uterus into the vascular mesometrium 


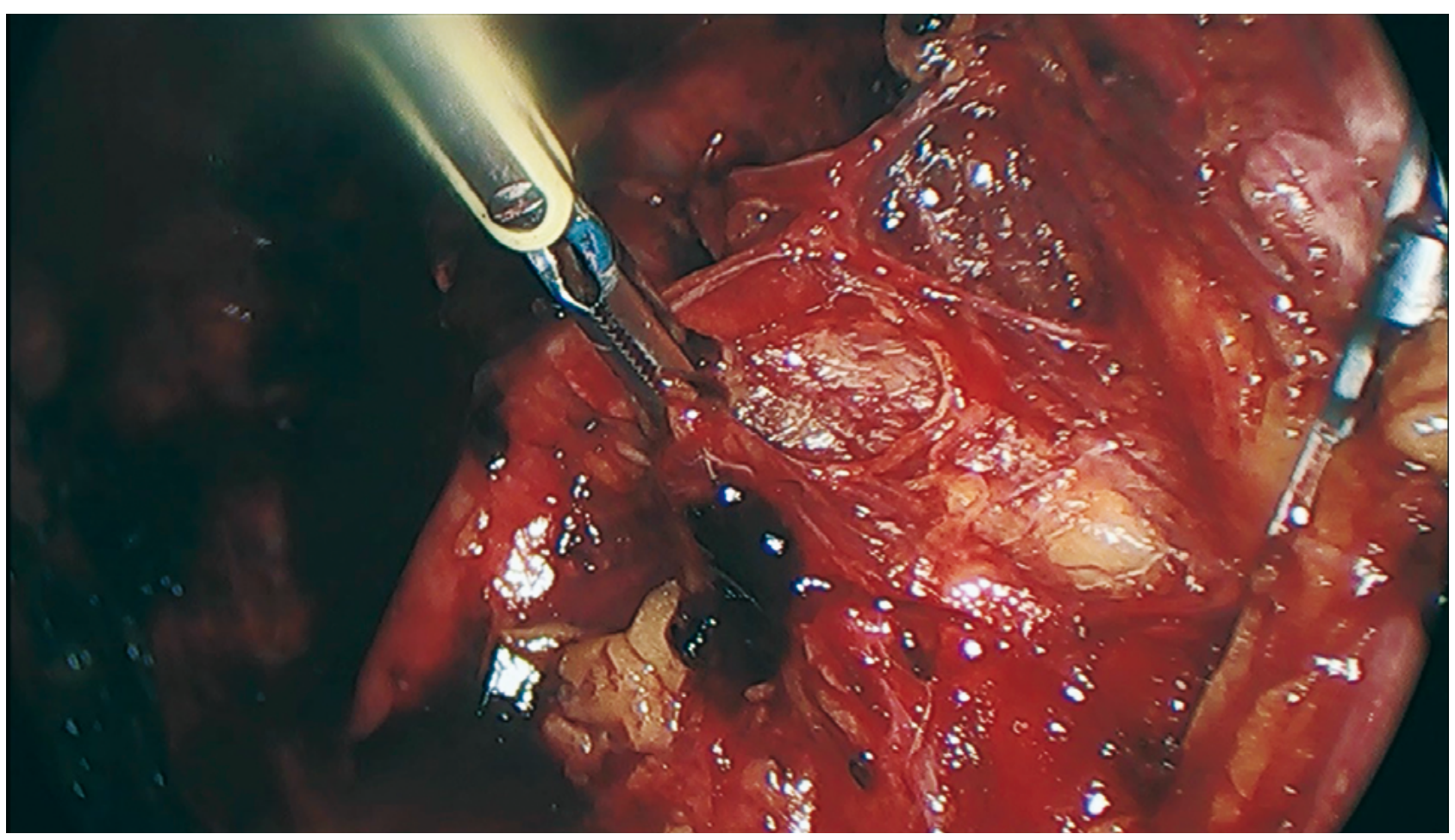

Fig. 2. Superior hypogastric plexus

(part of the cardinal ligament) and ligamentous mesometrium (uterosacral and uterorectal ligaments). The vesicouterine ligament is part of the bladder mesentery and can be spared in most cases. The procedure is currently relatively commonly used in Germany, but the latest multi-center studies showed a statistically higher problem with defecation and bowel problems, induced probably by the destruction of the ligamentous mesometrium ${ }^{(10)}$.

In 2008, Querleu and Morrow described the current ESGO classification of radical hysterectomy, which in the $\mathrm{C} 1$ type is compared with the nerve-sparing technique ${ }^{(11)}$. The classification is adjusted to the cancer stage and includes components of all of the techniques presented above.

\section{ANATOMY OF NERVE STRUCTURES}

The abdominal aortic plexus is situated on both lateral sides and in front of the aorta between the origins of the superior and inferior mesenteric arteries. The hypogastric nerve enters the sympathetic chain at T10-L2. The routes are essential for the contraction of the internal urethral sphincter. Injuries of the hypogastric nerve may cause urinary dysfunction in female patients, and lead to incontinence ${ }^{(12)}$. Retroaortic lymph nodes should be dissected with special attention to the lumbar vessels and the affluent vein. A lumbar artery injury may cause infarction of the spinal cord. The superior hypogastric plexus enters the pelvis dividing it into the right and left hypogastric nerves which descend (on the anterior surface of the sacrum) to the lateral aspect of the rectum within the so-called "hypogastric sheaths" and merge with the pelvic splanchnic nerves to form the left and right inferior hypogastric plexuses. From the plexus, the sympathetic fibers are carried into the pelvis as two main trunks - the right and left hypogastric nerves each lying medial to the internal iliac artery and its branches. The right and left hypogastric nerves continue as the inferior hypogastric plexus; these hypogastric nerves send sympathetic fibers to the ovarian and ureteric plexuses which originate within the renal and abdominal aortic sympathetic plexuses. The superior hypogastric plexus receives contributions from the two lower lumbar splanchnic nerves (L1-L2), which are branches of the chain ganglia. They also contain parasympathetic fibers arising from the pelvic splanchnic nerve (S2-S4), and ascend from the inferior hypogastric plexus; it is more typical for these parasympathetic fibers to ascend to the left-handed side of the superior hypogastric plexus and cross the branches of the sigmoid and left colic vessel branches, as these parasympathetic branches are distributed along the branches of the inferior mesenteric artery. The superior hypogastric plexus is the continuation of the abdominal aortic plexus. The nerves of the superior hypogastric plexus return to the spinal cord through the lumbar splanchnic nerves. The superior hypogastric plexus or the presacral nerve is located in the interiliac triangle overlying the sacral promontory. At this location, the presacral nerve is in close proximity to the major vasculature (bifurcation of the aorta, common iliac arteries, left common iliac vein, and inferior mesenteric artery) and the ureters. The inferior hypogastric plexus is a network (plexus) of nerves that supplies the organs of the pelvic cavity. The inferior 
hypogastric plexus gives rise to the prostatic plexus in males and the uterovaginal plexus in females (Figs. 1 and 2).

\section{PARAAORTIC NERVE-SPARING LYMPH NODE DISSECTION}

\section{Transperitoneal access}

For lymph node dissection, the commonly used access route is the transperitoneal approach. It is employed both in open surgery and laparoscopy. To perform a nerve-sparing surgical procedure, the initial step is to identify the superior hypogastric plexus and the hypogastric nerves. The easiest way to achieve this is to cut the peritoneum presacral and to find the hypogastric plexus over the bifurcation of the aorta. Another method involves identifying the hypogastric nerves on both sides, which go to the common iliac vessels. Next, they should be followed to the hypogastric plexus over the bifurcation. A study by Muallem shows that the most important structure for the identification of the nerves is the inferior mesenteric ganglion localized lateral to the aorta close to the inferior mesenteric artery or about $1 \mathrm{~cm}$ caudal from it ${ }^{(2)}$. The ganglion can be easily found if the surgeon follows the nerves from the superior hypogastric plexus which are going cranial. The connections of the mesenteric ganglion with the sympathetic cord are the inferior and superior lumbar splanchnic nerves. On the right side, the sympathetic trunk is located dorsal of the vena cava, and on the left side lateral to the aorta. Paracaval lymph node dissection can be performed without injury to the neural structures with no problems. The interaortocaval dissection must be done precisely with the previous dissection of the lumbar splanchnic nerves to maintain the nerve-sparing nature of the surgery. On the right side, the neural connections are shorter, but they can be identified in the same manner as on the right side.

\section{Retroperitoneal access}

The nerve-sparing is easier to perform if the retroperitoneal access is used for laparoscopy. The retroperitoneal approach performed by the author is made after prior transperitoneal subumbilical trocar insertion and control of the abdominal cavity. Then, an incision is made about $2 \mathrm{~cm}$ cranial and $3 \mathrm{~cm}$ medial from the spina iliaca anterior superior. The skin is incised, and the subcutaneous fatty tissue is dissected. Next, the fascia is incised, and the retroperitoneum is dissected bluntly with the index finger. A $12 \mathrm{~mm}$ trocar is placed, so that the inner border of it can be seen under the peritoneum. Then the trocar is blocked (we used a balloon trocar), and the pneumoretroperitoneum is made up to the pressure of $10 \mathrm{~mm} \mathrm{Hg}$. A camera is placed, and another two trocars are placed: a $5 \mathrm{~mm}$ trocar cranial in the clavicular line, and a $10 \mathrm{~mm}$ trocar cranial and dorsal from the camera trocar in the anterior axillary line. One $5 \mathrm{~mm}$ accessory trocar can also be placed cranial and
After reaching the retroperitoneum, the ureter and gonadal vein can be seen. The dissection of the common iliac artery to the aorta and the presacral space show the nerve structures which are then located in the upper part of the operative field. The lumbar splanchnic nerve can be followed to the sympathetic trunk and can be spared. Following the dissection of the preaortic space and precaval space the nerves on the right side can also be spared. This technique seems to be easier for the author for the precise identification of the nerve structures. A meticulous description of the anatomy and technique is shown in a study by Ray and Kumar ${ }^{(13)}$.

\section{RADICAL HYSTERECTOMY}

Radical hysterectomy was actually the first nerve-sparing procedure in gynecologic oncology. Currently, the guidelines issued by the European Society of Gynaecological Oncology for radical hysterectomy are based on the classification system by Querleu and Morrow. Radical hysterectomy A, B and $\mathrm{C} 1$ are actually the nerve-sparing operations. In turn, Höckel introduced the nerve-sparing technique of TMMR, in which the operator removes the embryonal structures of the Mullerian compartment and spares the nerve structures. It can be similar to the $\mathrm{C} 1$ hysterectomy, but much more structures are removed in the TMMR approach. A search of the available databases spanning the last 2 years revealed a far more precise technique reported by Muallem, and we will focus on it ${ }^{(14)}$.

If a radical nerve-sparing procedure can be performed, the avascular spaces of the pelvis need to be known. The most important of them are:

- Okabayashi space between the ureteral mesentery with the hypogastric nerve and the peritoneum;

- pararectal space between the ureteral mesentery and internal iliac vessels laterally, sacral bone cranially and vascular mesometrium caudally;

- paravesical space (triangular) between the obliterated umbilical artery (lateral umbilical ligament) and the external iliac vessels laterally and pelvic bone caudally.

The step-by-step operation described below is as reported by Muallem et al. ${ }^{(14)}$.

After preparing the paravesical and pararectal spaces, the lateral parametrium (uterine artery and vein and their acompanying lymph tissue), the dorsal parametrium (sacrouterine ligament), and the ventral parametrium (vesicouterine ligament) can be identified. The next step is the identification of the hypogastric nerves bilaterally and the superior hypogastric plexus at the lateral side of the rectum about $2-3 \mathrm{~cm}$ caudal from the ureter.

When the hypogastric nerves bilaterally are isolated, the dorsal parametrium (sacrouterine ligament) and the dorsal paracolpium (sacrovaginal ligament) are resected to the tendinous arch of the pelvic fascia (fascia pelvis visceralis).

The uterine artery and vein (lateral parametrium) are resected at the internal iliac artery and vein, and prepared to the middle point above the ureter. 
The ventral parametrium is prepared by entering the ureter tunnel medial from the ureter and rolling the ureter itself laterally and ventrally to the pelvic sidewall and pubic symphysis. Here, a small artery arising from the uterine artery and ending in the ureter (the ureteral branch of uterine artery), and a small vein going from the ureter to the uterine vein (ureteral vein), can be identified. After the isolation and cutting of all these three branches, the resection of the ventral parametrium is completed, and the ureter can be then completely unroofed.

At the internal iliac vessels, two groups of vessels, including the inferior vesical artery and vein (the last medial branch of internal iliac vessels), the vaginal vein (often wrongly referred to as the deep uterine vein), and in 50\% of cases thel vaginal artery, can be identified.

By cutting the vaginal vessels (lateral paracolpium) only and directly at the level of the internal iliac vessels, the pelvic splanchnic nerves can be revealed. The nerves run directly from the sacral roots in front of the common trunk of the internal pudendal and inferior gluteal vessels at the dorsal edge of the lesser sciatic foramen, and then medial from the inferior vesical vein cranially to merge in the inferior hypogastric plexus behind the ascending vaginal vessels. The vaginal vein shows two vein anastomoses with the inferior vesical vein. These two veins with the accompanying lymph tissue build the vesicovaginal ligament (ventral paracolpium). Isolating these two veins and resecting them directly beneath the bladder reveals the bladder branches of the inferior hypogastric plexus.

Mediodorsal from the bladder branches, lateral from the vaginal wall, and above the level of hypogastric nerve, a small space (hollow) can be developed. This space allows the operator to isolate the inferior hypogastric plexus from the lateral vaginal wall, and to isolate the uterine branches of the inferior hypogastric plexus to be resected from the pelvic autonomic nervous system. At this point, the uterus is connected only to the vagina. The uterus and vagina are then very well mobilized, and the vaginal cuff can be easily adjusted. The vagina can be closed from the abdomen with sutures or with the Wertheim clamps, and cut off. The vagina can also be closed vaginally like in Shouta's procedure. This step is very important after the results of the LACC study, so that no contact of the tumor with the abdominal cavity and peritoneum is allowed.

\section{DISCUSSION}

Advances in surgical treatment based on technical progress offer an opportunity to operate better and more precisely. Electrosurgical tools enable better dissection and preservation of nerve structures ${ }^{(15)}$.

As Ziętek-Strobl and Kozłowski show in their studies, the radicality of surgery affects the patients' life. The effects have been found to depend on the range and extension of the radical operation $^{(16,17)}$.

Radical hysterectomy is associated with multiple complications, the most common of which is impaired bladder voiding function. Rectal function and defecation can also be adversely affected. In a study by Kozłowski et al. the sexual functions were also impaired. On the one hand, it is a psychological problem caused by the patients' oncological disease, on the other it relates to the affected nerve function of the vagina, which may decrease the quality of sexual life $\mathrm{f}^{(17)}$. In the Cochrane analysis by Kietpeerakool et al., there were no benefits from the nerve-sparing technique compared to the common radical hysterectomy in patients with early cervical cancer ${ }^{(18)}$. However, the analysis failed to describe in detail the operative techniques of radical hysterectomy. An insufficiently radical procedure could also not affect the nerve structures. This is the bias which may account for the fact that the results are not different between these two procedures.

The most important argument against the nerve-sparing technique is the perineural spread of the tumor. In the cervical cancer, the risk ranges for 7 to $35 \%{ }^{(19)}$. Using imaging techniques, there is no possibility to show perineural invasion. Detailed studies focusing on the histological assessment, for example with frozen sections, are needed for optimization of the operative technique by adjusting it to the patient.

\section{CONCLUSION}

Nerve-sparing surgery in gynecologic oncology is our future, and better quality of life and greater patient satisfaction should be our goals. They can be pursued using these techniques, but they need to be adopted to the specific needs of the patient because of the risk of perineural invasion. Studies are needed for better examination and comparison of the presented systematic nerve-sparing operation of lymphadenectomy in ovarian and endometrial cancers, and also combined with nerve-sparing radical hysterectomy.

\section{Conflict of interest}

The authors do not report any financial or personal affiliations to persons or organizations that could negatively affect the content of or claim to have rights to this publication.

\section{References}

1. Muallem MZ, Armbrust R, Neymeyer J et al.: Nerve sparing radical hysterectomy: short-term oncologic, surgical, and functional outcomes. Cancers (Basel) 2020; 12: 483.

2. Muallem MZ, Diab Y, Jöns T et al.: Nerve-sparing systematic lymph node dissection in gynaecological oncology: an innovative neuro-anatomical and surgical protocol for enhanced functional outcomes. Cancers (Basel) 2020; 12: 3473.

3. Carter JS: Radical hysterectomy. Medscape. WebMD. Sep 20, 2019. Available from: https://emedicine.medscape.com/ article/270723-overview.

4. Latzko W, Schiffmann J: Klinisches und Anatomisches des zur Radikaloperation des Gebarmutterkrebses (nach einem am 24. Juni 1919 gehaltenen Vortrag). Diskussionsbemerkungen, Weibel W und Wertheim E. Zbl Gynäk 1919; 43: 715-719. 
5. Okabayashi H: Radical abdominal hysterectomy for cancer of cervix uteri. Surg Gynecol Obstet 1921; 33: 335-341.

6. Meigs JV: Radical hysterectomy for cancer of the cervix with bilateral pelvic lymphadenectomy (the so-called Wertheim Operation). In: Meigs JV (ed.): Progress in Gynecology. Vol. 1, Grune \& Stratton, New York 1950: 540-560.

7. Yabuki Y, Asamoto A, Hoshiba T et al.: Dissection of the cardinal ligament in radical hysterectomy for cervical cancer with emphasis on the lateral ligament. Am J Obstet Gynecol 1991; 164: 7-14.

8. Yabuki Y: Twenty-first century radical hysterectomy - journey from descriptive to practical anatomy. Gynecol Oncol Rep 2020; 34: 100623.

9. Höckel M, Konerding MA, Heussel CP: Liposuction-assisted nerve-sparing extended radical hysterectomy: oncologic rationale, surgical anatomy, and feasibility study. Am J Obstet Gynecol 1998; 178: 971-976.

10. Chiantera V, Vizzielli G, Lucidi A et al.: Laparoscopic radical hysterectomy in cervical cancer as total mesometrial resection (L-TMMR): a multicentric experience. Gynecol Oncol 2015; 139: 47-51.

11. Querleu D, Morrow CP: Classification of radical hysterectomy. Lancet Oncol 2008; 9: 297-303.

12. Li L, Bi Y, Wang L et al.: Identification and injury to the inferior hypogastric plexus in nerve-sparing radical hysterectomy. Sci Rep 2019; 9: 13260.
13. Ray MD, Kumar N: High alert zones in nerve-sparing retroperitoneal lymph node dissection in gynecologic cancers: a precise anatomy and safe surgical technique. J Gynecol Surg 2020; 36: 331-336.

14. Muallem MZ, Jöns T, Seidel N et al.: A concise paradigm on radical hysterectomy: the comprehensive anatomy of parametrium, paracolpium and the pelvic autonomic nerve system and its surgical implication. Cancers (Basel) 2020; 12: 1839.

15. Sakuragi N, Murakami G, Konno Y et al.: Nerve-sparing radical hysterectomy in the precision surgery for cervical cancer. J Gynecol Oncol 2020; 31: e49.

16. Ziętek-Strobl A, Futyma K, Kuna-Broniowska I et al.: Urogynaecological symptoms among oncological survivors and impact of oncological treatment on pelvic floor disorders and lower urinary tract symptoms. A six-month follow-up study. J Clin Med 2020; 9: 2804

17. Kozłowski M, Gargulińska P, Ustianowski $€$ et al.: Sexuality of women after gynecological surgeries. Healthcare (Basel) 2020; 8: 393 .

18. Kietpeerakool C, Aue-Aungkul A, Galaal K et al.: Nerve-sparing radical hysterectomy compared to standard radical hysterectomy for women with early stage cervical cancer (stage Ia2 to IIa). Cochrane Database Syst Rev 2019; 2: CD012828.

19. Zhu $Y$, Zhang GN, Shi $Y$ et al.: Perineural invasion in cervical cancer: pay attention to the indications of nerve-sparing radical hysterectomy. Ann Transl Med 2019; 7: 203. 